\title{
In-vitro cytotoxic effects of Solanum macranthum fruit. Dunal extract with antioxidant potential
}

\author{
Vishal U. Kalebar ${ }^{1,2}$, Joy H. Hoskeri ${ }^{3}$, Shivaprakash V. Hiremath ${ }^{2}$ and Murigendra B. Hiremath ${ }^{1 *}$
}

\begin{abstract}
Background: The current study undertaken to evaluate antioxidant property of Solanum macranthum fruit methanol extract and its in-vitro cytotoxic effects on breast cancer MDA-MB-231 and mice embryo fibroblast (MEF-L929) cell line.

Methods: The total alkaloids, phenols and flavonoids content in the methanol extract of S.macranthum fruit were estimated. The antioxidant activity was evaluated by FRAP assay, $\mathrm{H}_{2} \mathrm{O}_{2}$ scavenging assay and DPPH assay. Antiinflammatory protein denaturation inhibition assay was carried out using bovine serum albumin. Anticancer property of the extract was evaluated against breast cancer MDA-MB-231 by MTT assay and comparative study was carried out on normal cells using MEF-L929 cell line.

Results: Phytochemical estimation revealed that total alkaloid content was measurable high ( $13.6 \mathrm{~g} / 100 \mathrm{~g}$ of extract), where as the total phenolics and flavonoids content was $115.5 \mathrm{mg} / \mathrm{GAE}$ and $142.6 \mathrm{mg} / \mathrm{QE}$. Further, the antioxidant effect of methanol extract by $\mathrm{H}_{2} \mathrm{O}_{2}$ assay showed considerably higher scavenging activity with $99.6 \% \mathrm{at} 400 \mathrm{\mu g} / \mathrm{ml}$, where as by FRAP assay the relative reducing power was estimated to be $39.1 \%$ at $400 \mu \mathrm{g} / \mathrm{ml}$ and in case of DPPH assay it was found to be $47.9 \%$ at $400 \mu \mathrm{g} / \mathrm{ml}^{\text {. }} \mathrm{EC}_{50}$ value of anti-inflammatory assay was found to be $112.96 \mu \mathrm{g} / \mathrm{ml}$. Anticancer studies showed that the $\mathrm{IC}_{50}$ value was found to be $373.77 \mu \mathrm{g} / \mathrm{ml}$ against MDA-MB-231 breast cancer cell line, where as the methanol extract showed negligible cytotoxic effect against normal cells (MEF -L929 cell line), indicating its cancer specific effect.

Conclusion: Based on the results obtained, methanol extract of Solanum macranthum fruit was found to possess significant antioxidant properties and also showed potential anticancer property against MDA-MB-231 breast cancer cell line with negligible cytotoxic effect on normal cells revealing its potential application as an anticancer agent.
\end{abstract}

Keywords: Antioxidant activity, Anti-inflammatory, cytotoxic effect, Breast Cancer; MDA-MB-231; MEF-L929 cell lines

\section{Introduction}

Globally Breast Cancer ranks second cause of death (i.e., overall 522,000 deaths annually) with the mortality rate of 6 per 100,000 in Eastern Asia and 20 per 100,000 in Western Africa (Globocan 2018). Among the Indian population breast cancer is Highest compared to other cancer with ASR incidences of 25.76 per 100,000 women with the death ratio of 2:1 (out of two newly diagnosed

\footnotetext{
* Correspondence: murigendra@gmail.com

${ }^{1}$ Department of Biotechnology and Microbiology, Karnatak University,

Dharwad, Karnataka, India

Full list of author information is available at the end of the article
}

breast cancer in women one dies) and the estimated incidence rate of 200,000 new diagnosed cases per year by 2030 [1-3]. Development of proper treatment against cancer has been a continuous global effort, with regard to this many of the natural products are being tested against various cell lines to identify and develop a potential anticancer agent. The currently available cancer treatment includes chemotherapy, radiation therapy, hormonal therapy and surgical removal of breast [4]. But these treatments generally pose life threatening side effects on morbid and economic week population of developing countries like India and also such population

\section{Springer Open}

(c) The Author(s). 2020 Open Access This article is licensed under a Creative Commons Attribution 4.0 International License, which permits use, sharing, adaptation, distribution and reproduction in any medium or format, as long as you give appropriate credit to the original author(s) and the source, provide a link to the Creative Commons licence, and indicate if changes were made. The images or other third party material in this article are included in the article's Creative Commons licence, unless indicated otherwise in a credit line to the material. If material is not included in the article's Creative Commons licence and your intended use is not permitted by statutory regulation or exceeds the permitted use, you will need to obtain permission directly from the copyright holder. To view a copy of this licence, visit http://creativecommons.org/licenses/by/4.0/. 
cannot afford the expensive synthetic drugs. According to the reports of National Cancer Institute (NCI) 35,000 plant species possess anticancer properties and as per the reports of World Health Organization (WHO), 252 molecules are FDA approved anticancer drugs, out of which $11 \%$ are derived from plants. India is considered to be possessing rich source of medicinal plants and hence poses major producer of plant based medicine owing upto 25,000 effective plant-based formulations used in ethanobotanical communities in India, with many reports available on anticancer property of plant extracts, but their respective bioactive phytochemicals have remained unexplored [5]. The present investigation is focused on unmasking the anticancer property of an important plant Solanum manranthum Dunal (syn. S. wrightii Benth) or 'Giant Potato tree', which is a shrub and an ornamental plant [6]. Solanum "Sunberry" (Solanaceae) consisting of approx 2700 species, covering nearly $60 \%$ species of the solanaceas family [7]. The solanaceae family exhibits a vivid variety of medicinal properties including antimicrobial, anti-inflammatory, antioxidant as well as anticancer application [8]. With this background the present investigation was undertaken to assess the anticancer potential of S.macranthum fruit extract. This investigation has also focused on validation of cancer specific effect of S.macranthum fruit extract through evaluation of its non-toxic property against normal cells in order to set a platform for its use as an anticancer agent.

\section{Materials and methods}

The Solanum macranthum plant Fruit was collected from the medicinal garden of K.L.E's P. C Jabin Science Hubballi. The fruits were dried and subjected to sequential extractions using Petroleum ether, Chloroform, Methanol and water solvents. The qualitative analysis of all the solvents extracts revealed thatmethanol extract of S.macranthum fruit possesed more phytochemical profile than the other solvent extract which has been discussed in detail in our pervious studies [8]. Therefore, the present investigation was carried out using methanol extract of S.macranthum fruit.

\section{Determination of Total alkaloids}

S.macranthum fruit methanol extract (5gm)was transferred to $150 \mathrm{ml}$ of acetic acid (20\%). The mixture was incubated for $4 \mathrm{~h}$ at room temperature and filtered. The filtrate was heated on boiling water bath until the mixture was reduced to one fourth of its volume. The filtrate was cooled and ammonium hydroxide solution was added drop wise until the occurrence of the precipitation in the filtrate was ceased. The precipitate formed was allowed to settle down and filtered. The percentage of the alkaloid was determined applying the formula to dried filtrate of alkaloid obtained from the extract [9]. The results were analyzed in triplicate.

$$
\begin{array}{r}
\text { Percentage of total alkaloids }(\%)=\text { Weight of residue } / \\
\text { Weight of sample taken } \times 100
\end{array}
$$

\section{Determination of Total flavonoids}

The estimation of total flavonoids was carried out by following method described by Zhishen et.al. [10]. $20 \mu \mathrm{g}$ of the methanol extract and aliquots of standard quercetin ranging from 10 to $50 \mu \mathrm{g}$ was diluted up to $1 \mathrm{ml}$ using absolute methanol. $200 \mu \mathrm{l}$ of distill water and $150 \mu \mathrm{l}$ of (5\%) sodium nitrate was added to the dilution. After incubating the mixture for $5 \mathrm{~min}, 150 \mu \mathrm{l}$ of (10\%) aluminium chloride was added and incubated for further $6 \mathrm{~min} .2 \mathrm{ml}$ of $(4 \%)$ sodium hydroxide was added and kept for $15 \mathrm{~min}$ at room temperature. The development of pink colour indicates the presence flavonoids, which was measured at $510 \mathrm{~nm}$ (Labman UV Visible Spectrophotometer: LMSP-UV1200PC). The total flavonoid was tabulated using calibration curve and the results were analyzed in triplicates.

\section{Determination of Total phenols}

Total phenol content was determined by Folins-phenols reagent method described by Siddhuraju et.al. 2003 [11]. $20 \mu \mathrm{g}$ of the methanol extract of the fruit was diluted up to $1 \mathrm{ml}$ using distilled water. To this $500 \mu \mathrm{l}$ of diluted Folins-phenols reagent ( $1: 1$ with water) and $2.5 \mathrm{ml}$ of sodium carbonate were added. The mixture was incubated for $40 \mathrm{~min}$ in dark until the colour develops. The absorbance was measured at $725 \mathrm{~nm}$ (Labman UV Visible Spectrophotometer: LMSP-UV1200PC). Gallic acid (10$50 \mu \mathrm{g} / \mathrm{ml}$ ) was used to construct the calibration curve. The results were analyzed in triplicate. The total phenol of methanol extract was expressed (mg of gallic acid) using standard graph.

\section{Determination of antioxidant property by in-vitro assays Ferric ion reducing antioxidant power (FRAP) assay}

The total antioxidant capacity of the methanol extract was evaluated by the FRAP assay method with slight modifications according to the procedure described by Benzie and

Table 1 Phytoconstituents present in the S.macranthum Fruit methanol extract (SMFE)

\begin{tabular}{llllllllll}
\hline Parameters & Alkaloids & Flavonoids & Glycosides & Phenols & Saponins & Tannins & Terpeniods & Steroids & Carbohydrates \\
\hline SMFE & ++ & ++ & ++ & ++ & ++ & + & + & & + \\
\hline
\end{tabular}

++:- Moderately Present, +:- poorly present, --:- Absent 


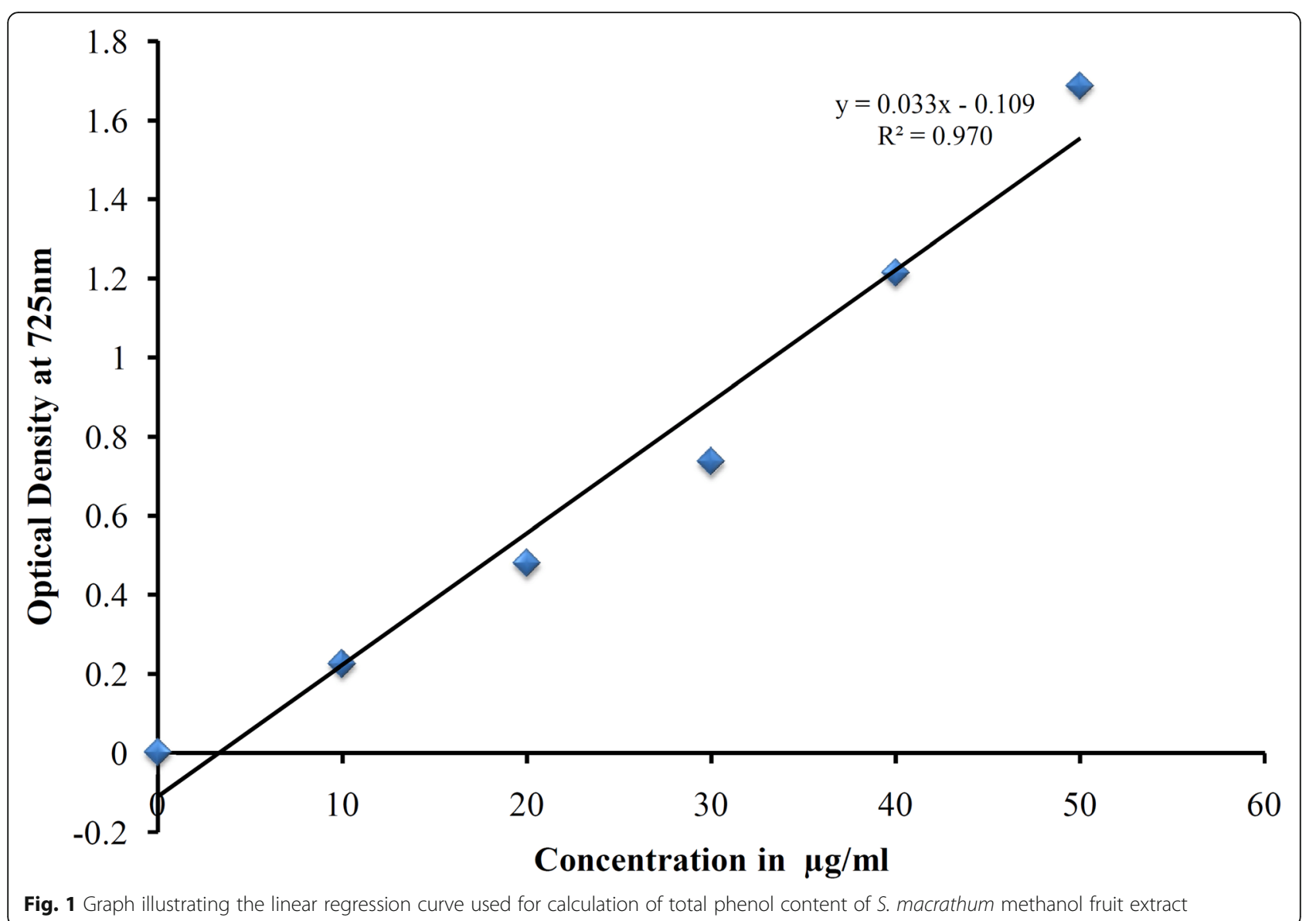

Strain 1996 [12] and the results were analyzed in triplicate. $0.5 \mathrm{~mL}$ of various concentrations $(25,50,100,200,400 \mu \mathrm{g} /$ $\mathrm{mL}$ ) of S.macranthum fruit methanol extract and standard were mixed with $2 \mathrm{ml}$ of freshly prepared FRAP reagent. The control used here contained the reagent but devoid of the extract or the drug. The reaction mixture was mixed thoroughly and incubated for $30 \mathrm{~min}$ under dark conditions. Absorbance was read at $593 \mathrm{~nm}$ (Labman UV Visible Spectrophotometer: LMSP-UV1200PC). Ascorbic acid is been used as reference standard.

$$
\begin{aligned}
& \text { Relative } \% \text { of reducing power } \\
& \quad=[(\text { As-Ac }) /(\text { Amax }-A c)] \times 100
\end{aligned}
$$

Where, 'As' is absorbance of Sample, 'Ac' is absorbance of control and Amax is highest absorbance of Standard.

\section{$\mathrm{H}_{2} \mathrm{O}_{2}$ scavenging assay}

Solution of hydrogen peroxide $(40 \mathrm{mM})$ was prepared in phosphate buffer (pH 7.4). S.macranthum fruit methanol extract $(25,50,100,200,400 \mu \mathrm{g} / \mathrm{mL})$ in distilled water were added to a $0.6 \mathrm{ml}$ of hydrogen peroxide solution (40 $\mathrm{mM}$ ) and final volume was adjusted to $1 \mathrm{ml}$ with distilled water. The control used here contained the reagent but devoid of the extract or the drug. Absorbance of hydrogen peroxide at $230 \mathrm{~nm}$ (Labman UV Visible Spectrophotometer: LMSP-UV1200PC) was determined $10 \mathrm{~min}$ later against a blank solution containing the phosphate buffer without hydrogen peroxide. The percentage of hydrogen peroxide scavenging of both methanol extract and standard compounds were calculated using the formula:

Table 2 Total Phenol content of S.macranthum Fruit methanol extract (SFME)

\begin{tabular}{ll}
\hline Concentration $\mu \mathrm{g} / \mathrm{ml}$ & Absorbance at $725 \mathrm{~nm}$ \\
\hline Control & $0.000 \pm 0.01$ \\
10 & $0.224 \pm 0.01^{* *}$ \\
20 & $0.478 \pm 0.01^{* *}$ \\
30 & $0.734 \pm 0.01^{* *}$ \\
40 & $1.212 \pm 0.01^{* *}$ \\
50 & $1.685 \pm 0.01^{* *}$ \\
SFME $(20 \mu \mathrm{g} / \mathrm{ml})$ & $0.185 \pm 0.01^{* *}$
\end{tabular}

Data is presented as mean standard error of the mean $(n=3)$. Statistical significance was assessed using one-way ANOVA. ${ }^{*}=p<0.05{ }^{* *}=p<0.01$. Significantly different in comparison with control 


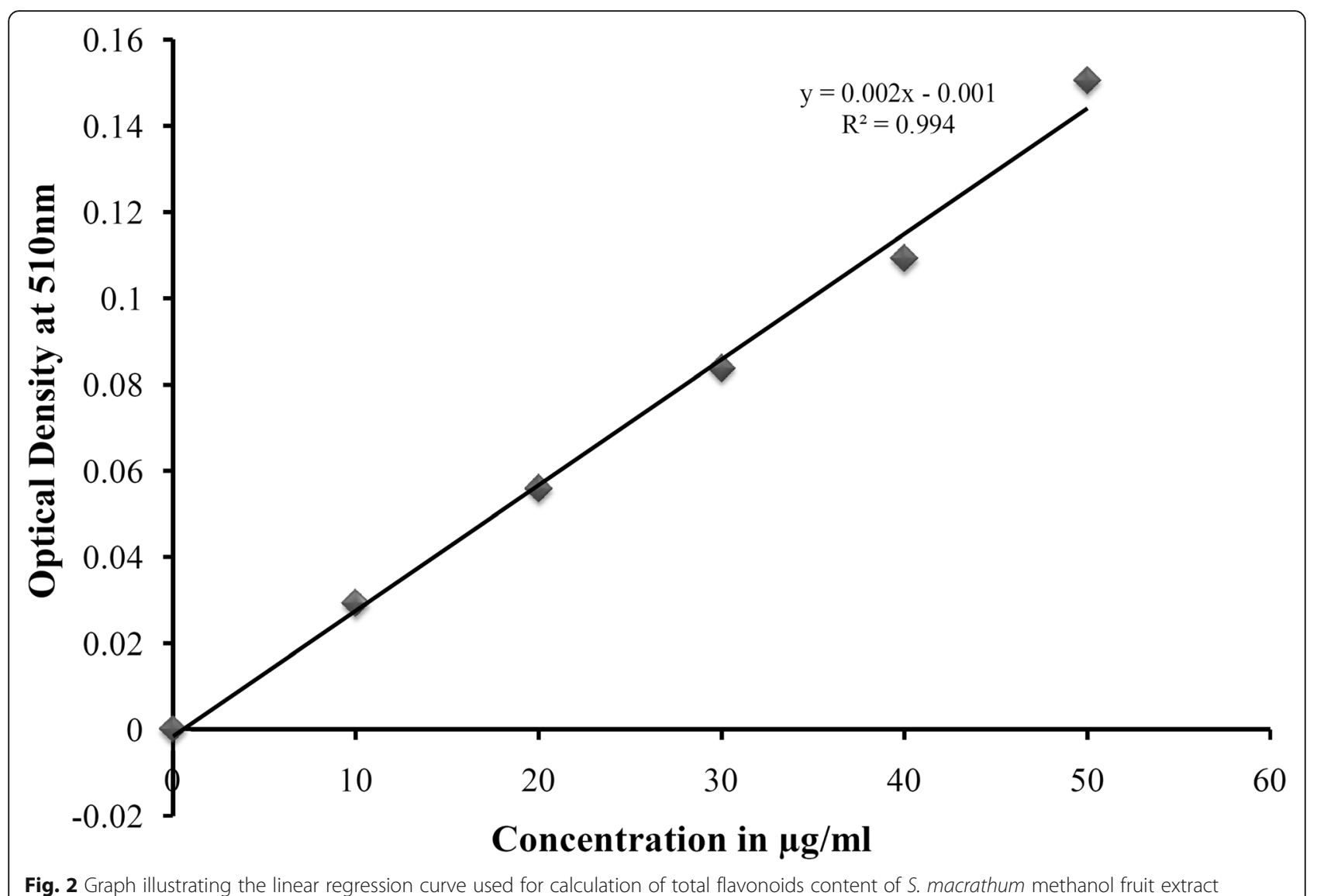

\%Scavenged $\left[\mathrm{H}_{2} \mathrm{O}_{2}\right]=\left[\left(\mathrm{A}_{\mathrm{C}}-\mathrm{A}_{\mathrm{S}}\right) / \mathrm{A}_{\mathrm{C}}\right] \times 100$.

Where $A_{C}$ is the absorbance of the control and $A_{S}$ is the absorbance of the sample of extracts or standards. Ascorbic acid was used as reference standard [13]. The results were analyzed in triplicate.

\section{2, 2-Diphenyl-1-picrylhydrazyl radical scavenging ability assay}

DPPH of $2 \mathrm{ml}$ working solution $(0.2 \mathrm{mM})$ was mixed with $0.5 \mathrm{ml}$ of different concentrations $(25,50,100,200$, $400 \mu \mathrm{g} / \mathrm{ml}$ ) of S.macranthum fruit methanol extract and standard solution followed by incubation for $30 \mathrm{~min}$ in dark at room temperature. The control used here contained the reagent but devoid of the extract or the drug The absorbance was measured at $517 \mathrm{~nm}$ (Labman UV Visible Spectrophotometer: LMSP-UV1200PC). The percent antioxidant or radical scavenging activity was calculated using the following formula:

$$
\% \text { Antioxidant activity }=[(\text { Ac-As }) / A c] \times 100
$$

Where, 'Ac' and 'As' are the absorbance of control and sample, respectively. Ascorbic acid is been used as reference standard [14]. The results were analyzed in triplicate.

\section{In vitro anti-inflammatory activity}

The anti inflammatory activity of methanol extract of $S$. macranthum fruits was assessed according to Chandra et al. 2012 [15] and Sangeetha et al. 2011 [16] using the inhibition of albumin denaturation method with slight modification and the results were analyzed in triplicate.

Test solution: $0.2 \% \mathrm{w} / \mathrm{v}$ aqueous solution of BSA $(100 \mu \mathrm{l})$ and test solution of different concentrations (50, $100,150,200$, and $250 \mu \mathrm{g} / \mathrm{ml}$ ) of methanol extract of $S$.

Table 3 Total Flavonoid content of S.macranthum Fruit methanol extract (SFME)

\begin{tabular}{ll}
\hline Concentration $\mu \mathrm{g} / \mathrm{ml}$ & Absorbance at $510 \mathrm{~nm}$ \\
\hline Control & $0.01 \pm 0.01$ \\
10 & $0.03 \pm 0.01^{* *}$ \\
20 & $0.06 \pm 0.01^{* *}$ \\
30 & $0.08 \pm 0.01^{* *}$ \\
40 & $0.11 \pm 0.01^{* *}$ \\
50 & $0.15 \pm 0.01^{* *}$ \\
SFME $(20 \mathrm{mg} / \mathrm{ml})$ & $2.85 \pm 0.01^{* *}$ \\
\hline
\end{tabular}

Data is presented as mean standard error of the mean $(n=3)$. Statistical significance was assessed using one-way ANOVA. ${ }^{*}=p<0.05^{* *}=p<0.01$. Significantly different in comparison with control 


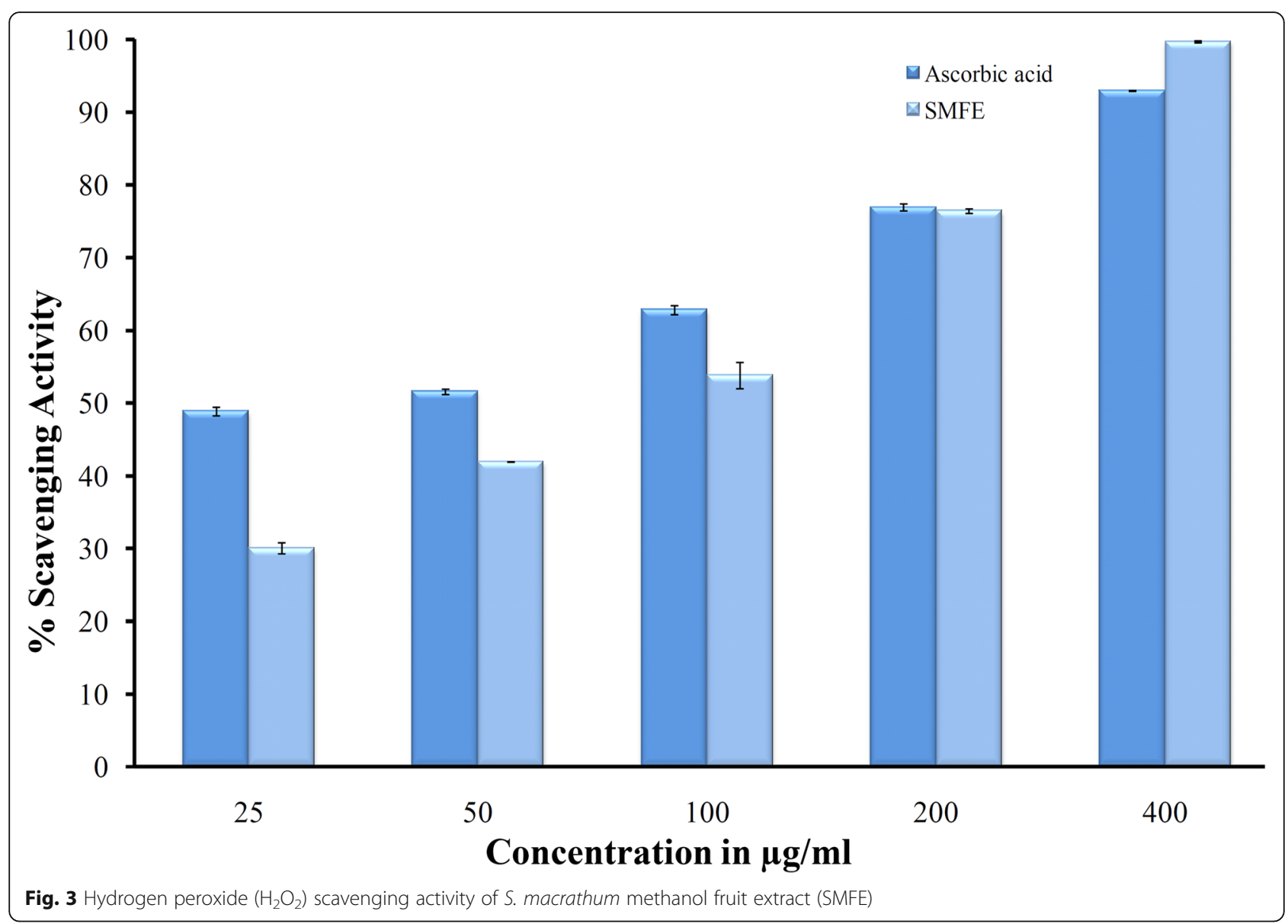

macranthum fruit along with phosphate buffer saline (PBS) pH 6.4 (2 ml) were used.

Test control solution: $0.2 \% \mathrm{w} / \mathrm{v}$ aqueous solution of BSA $(100 \mu \mathrm{l})$ and PBS $(2 \mathrm{ml})$ were used.

Standard solution: $0.2 \% \mathrm{w} / \mathrm{v}$ aqueous solution of BSA $(100 \mu \mathrm{l})$ and Diclofenac sodium $100 \mu \mathrm{g} / \mathrm{ml}$ was used.

The assay mixture was incubated at $37^{\circ} \mathrm{C}$ for $20 \mathrm{~min}$ followed by incubation at $70^{\circ} \mathrm{C}$ for $5 \mathrm{~min}$. The assay mixture was cooled and the absorbance was measured using Labman UV Visible Spectrophotometer: LMSPUV1200PC at $660 \mathrm{~nm}$. The absorbance values were determined by calculating the difference in the OD values of all the samples prior incubation and after incubation time. The control represents $100 \%$ protein denaturation. The percentage inhibition of protein denaturation was calculated by the following formula:

$\%$ of Inhibition $=\{($ Abs Control - Abs sample $) /$ Abs Control $\} \times 100$

Table 4 Antioxidant assays of S.macranthum Fruit methanol extract (SFME)

\begin{tabular}{|c|c|c|c|c|c|c|}
\hline \multirow[t]{2}{*}{$\begin{array}{l}\text { Concentration } \\
\mu \mathrm{g} / \mathrm{ml}\end{array}$} & \multicolumn{2}{|c|}{$\begin{array}{l}\text { DPPH Assay } \\
\text { Absorbance at } 517 \mathrm{~nm}\end{array}$} & \multicolumn{2}{|c|}{$\begin{array}{l}\text { FRAP Assay } \\
\text { Absorbance at } 593 \mathrm{~nm}\end{array}$} & \multicolumn{2}{|c|}{$\begin{array}{l}\mathrm{H}_{2} \mathrm{O}_{2} \text { Assay } \\
\text { Absorbance at } 230 \mathrm{~nm}\end{array}$} \\
\hline & Ascorbic acid & SFME & Ascorbic acid & SFME & Ascorbic acid & SFME \\
\hline Control & $1.4 \pm 0.01$ & $1.4 \pm 0.01$ & $0.35 \pm 0.01$ & $0.35 \pm 0.01$ & $0.74 \pm 0.01$ & $0.74 \pm 0.01$ \\
\hline 25 & $1.01 \pm 0.01^{* *}$ & $1.15 \pm 0.01^{* *}$ & $1.36 \pm 0.01^{* *}$ & $0.54 \pm 0.01^{* *}$ & $0.38 \pm 0.01^{* *}$ & $0.52 \pm 0.01^{* *}$ \\
\hline 50 & $0.95 \pm 0.02^{* *}$ & $1.13 \pm 0.01^{* *}$ & $1.90 \pm 0.01^{* *}$ & $0.58 \pm 0.01^{* *}$ & $0.36 \pm 0.01^{* *}$ & $0.43 \pm 0.01^{* *}$ \\
\hline 100 & $0.69 \pm 0.03^{* *}$ & $1.06 \pm 0.01^{* *}$ & $2.39 \pm 0.01^{* *}$ & $0.74 \pm 0.01^{* *}$ & $0.28 \pm 0.01^{* *}$ & $0.34 \pm 0.01^{* *}$ \\
\hline 200 & $0.42 \pm 0.01^{* *}$ & $0.96 \pm 0.01^{* *}$ & $2.56 \pm 0.03^{* *}$ & $0.97 \pm 0.01^{* *}$ & $0.17 \pm 0.01^{* *}$ & $0.18 \pm 0.01^{* *}$ \\
\hline 400 & $0.11 \pm 0.01^{* *}$ & $0.73 \pm 0.01^{* *}$ & $2.69 \pm 0.01^{* *}$ & $1.27 \pm 0.01^{* *}$ & $0.05 \pm 0.01^{* *}$ & $0.01 \pm 0.01^{* *}$ \\
\hline
\end{tabular}

Data is presented as mean standard error of the mean $(n=3)$. Statistical significance was assessed using one-way ANOVA. ${ }^{*}=p<0.05 * *=p<0.01$. Significantly different in comparison with control 


\section{Comparative cytotoxic evaluation of S.macranthum} methanol fruit extract on MDA-MB-231 and MEF-L929 cell line

Breast cancer MDA-MB-231 and noncancerous MEFL929 cell lines were obtained from National Centre for Cell Science (NCCS), Pune, India. The monolayer cell culture was trypsinized cells, were subcultured using Dulbecco modified eagles medium supplemented with $10 \%$ FBS, such that $200 \mu \mathrm{l}$ of suspension contains approximately 20,000 cells which was seeded to the $96 \mathrm{mi}-$ crotitre late and incubated at $37^{\circ} \mathrm{C}$ with $5 \% \mathrm{CO}_{2}$ atmosphere for $24 \mathrm{~h}$.

When partial monolayer was formed after $24 \mathrm{~h}$ of incubation the culture was aspirated, $200 \mu \mathrm{l}$ of different test concentrations $(100,200,300,400,500 \mu \mathrm{g} / \mathrm{ml})$ of methanol extract of S.macranthum fruit along with reference standard drug camptothecin $(15 \mu \mathrm{M})$ were added to the partial monolayer of the cell suspension of both the cell lines separately and incubated at $37^{\circ} \mathrm{C}$ with $5 \% \mathrm{CO}_{2}$ atmosphere for $24 \mathrm{~h}$. The drug containing media was aspirated and $10 \%$ MTT reagent was then added to each well and incubated at $37^{\circ} \mathrm{C}$ with $5 \% \mathrm{CO}_{2}$ atmosphere for $3 \mathrm{~h}$. After incubation, solubilisation of formazan occurred by the addition of $100 \mu \mathrm{L}$ di-methylsulfoxide. The percentage of inhibition was calculated in triplicate $(n=3)$ by measuring observance of microtitre plate at $570 \mathrm{~nm}$ and $630 \mathrm{~nm}$ using microtiter plate reader [17].

\section{Statistical analysis}

All the tests were carried out in triplets $(n=3)$ and statistically analyzed and is presented as mean \pm S.E. using ezANOVA statistical programme. Further Tukey's t-test was carried out and statistical significance of the result was determined where $\mathrm{e}^{*}$ refers to $p \leq 0.05$ and $*$ refers to $p \leq 0.01$.

\section{Results}

Phytochemical analysis

The qualitative analysis of the methanol extract were found to posses more phytoconstituents which was revealed by qualitative analysis indicating the presence of alkaloids, falvonoids, glycosides, phenols, saponins, tannins, terpenoids, steroids and carbohydrates which is briefed in the Table 1.

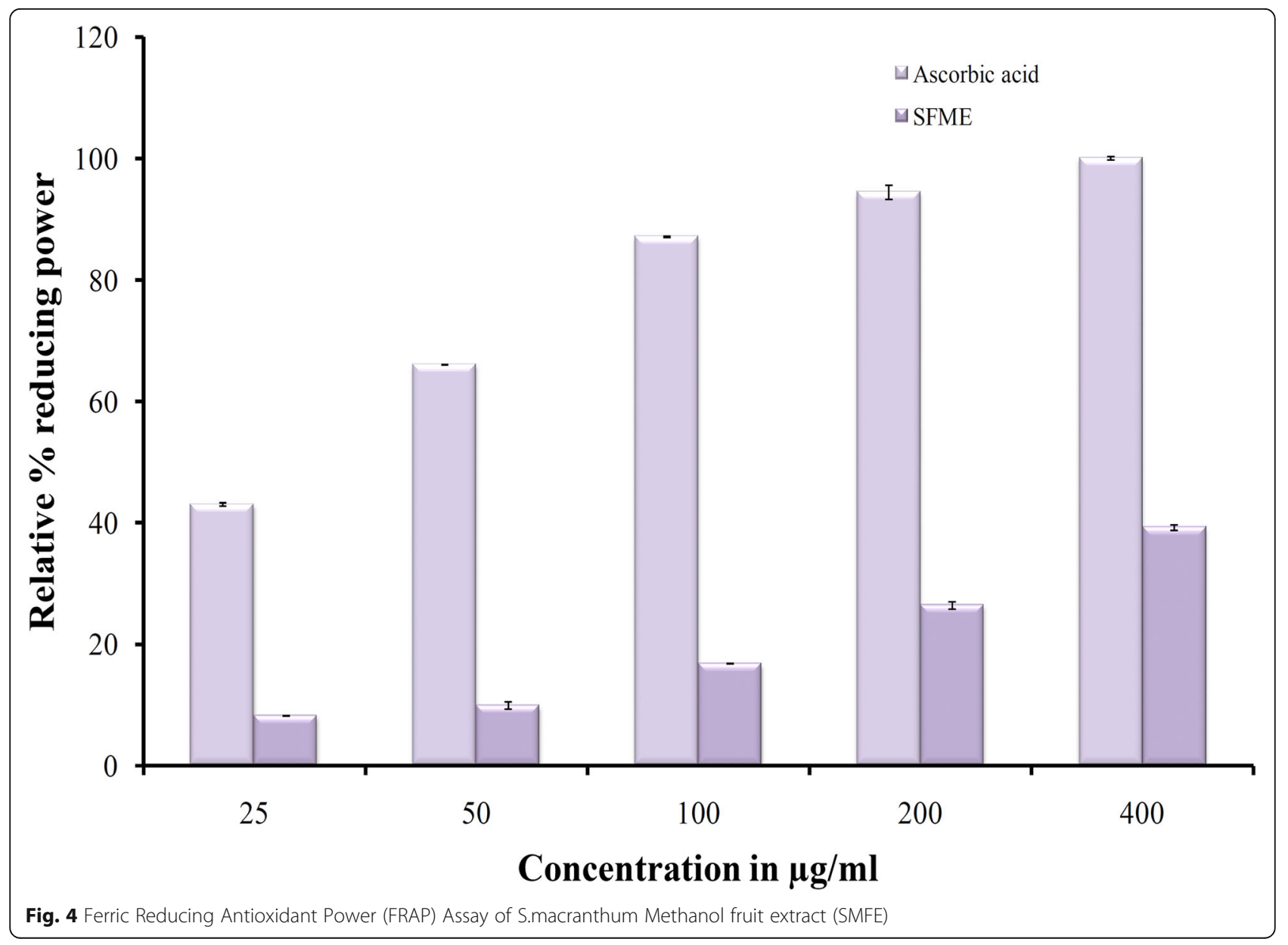


Total alkaloid content

The alkaloids of the methanol extract of S.macranthum fruit was determined by the method followed by Senguttuvan et.al. 2014 with slight modification. Gravimetric analysis for alkaloids content in the extract sample was found to be $13,600 \mathrm{mg} / 100 \mathrm{~g}$.

\section{Total phenols content}

Total phenols content of the methanol extract of S.macranthum fruit was estimated by using Gallic acid as standard. The total phenol present in the extract sample was found to be $115.5 \mathrm{mg} / \mathrm{GAE}$ which was calculated using the standard graph Fig. 1 and Table 2.

\section{Total flavonoids}

The total flavonoids content present in the methanol extract of S.macranthum fruit was found to be $142.6 \mathrm{mg} /$ quercetin equivalent, which was calculated using the standard graph Fig. 2 and Table 3.

\section{Antioxidant activity}

Hydrogen peroxide $\left(\mathrm{H}_{2} \mathrm{O}_{2}\right)$ scavenging activity

Hydrogen peroxide $\left(\mathrm{H}_{2} \mathrm{O}_{2}\right)$ scavenging activity of S.macranthum fruit methanol extract was carried out along with reference standard ascorbic acid. The results obtained revealed that effective concentration $\left(\mathrm{EC}_{50}\right)$ of methanol extract and standard was $97.24 \mu \mathrm{g} / \mathrm{ml}$ and $14.83 \mu \mathrm{g} / \mathrm{ml}$ respectively. At $200 \mu \mathrm{g} / \mathrm{ml}$ concentration the percentage of scavenging activity of methanol extract was significantly similar at par with reference standard ascorbic acid i.e., $76.38 \%$ and $76.89 \%$ respectively. Further with the increase in the concentration of $400 \mu \mathrm{g} / \mathrm{ml}$, methanolic extract antioxidant activity significantly increased and had higher percentage of scavenging activity when compared with standard reference ascorbic acid i.e., 99.6\% and 92.8\% respectively. Hydrogen peroxide $\left(\mathrm{H}_{2} \mathrm{O}_{2}\right)$ scavenging activity of S.macranthum fruit methanol extract along with standard reference ascorbic acid is depicted in Fig. 3 and Table 4.

\section{Ferric reducing antioxidant power (FRAP) assay}

The assay was based on reducing power of the antioxidant, where the reduction of ferric ion $\left(\mathrm{Fe}^{3+}\right)$ to the

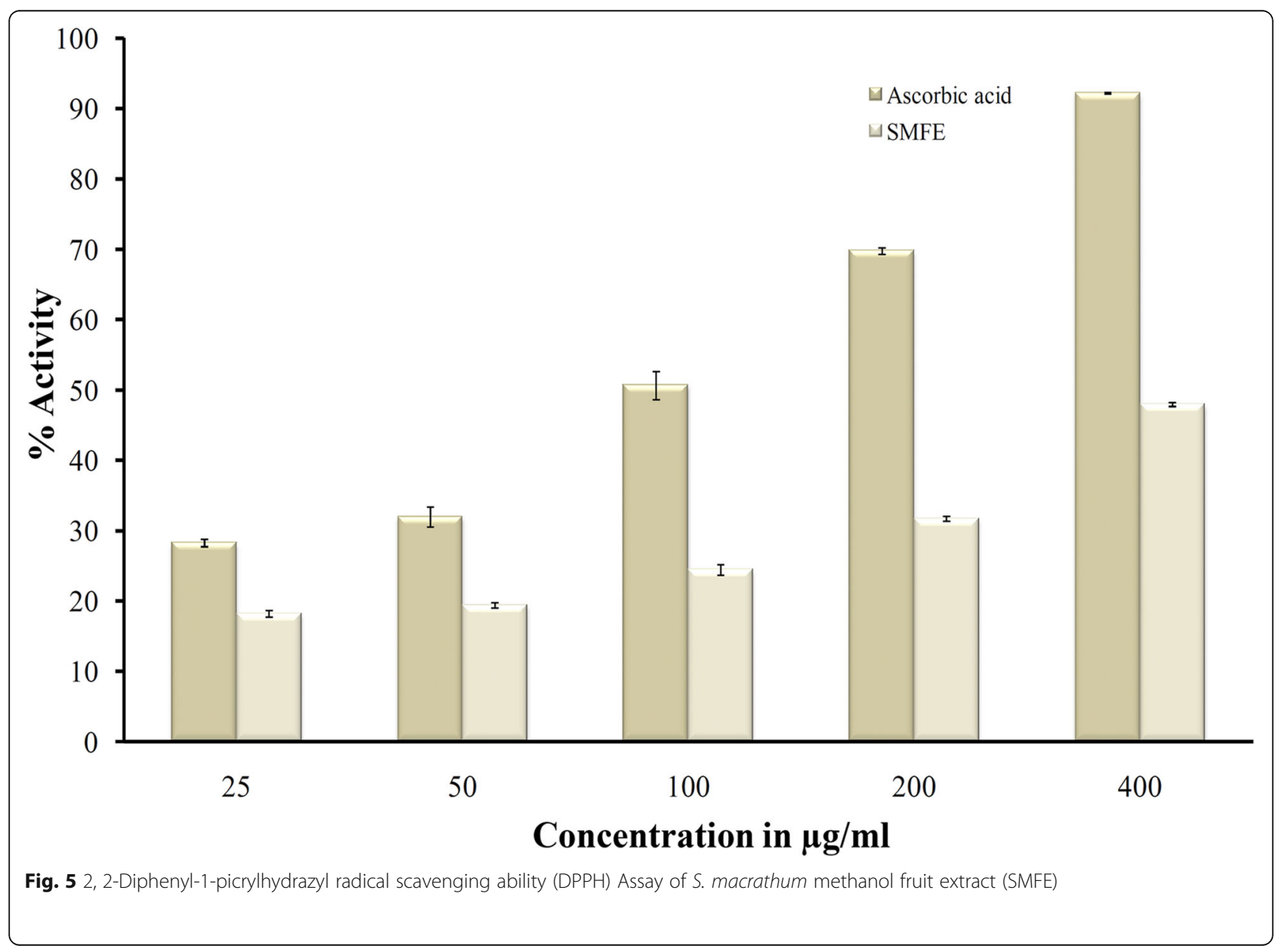




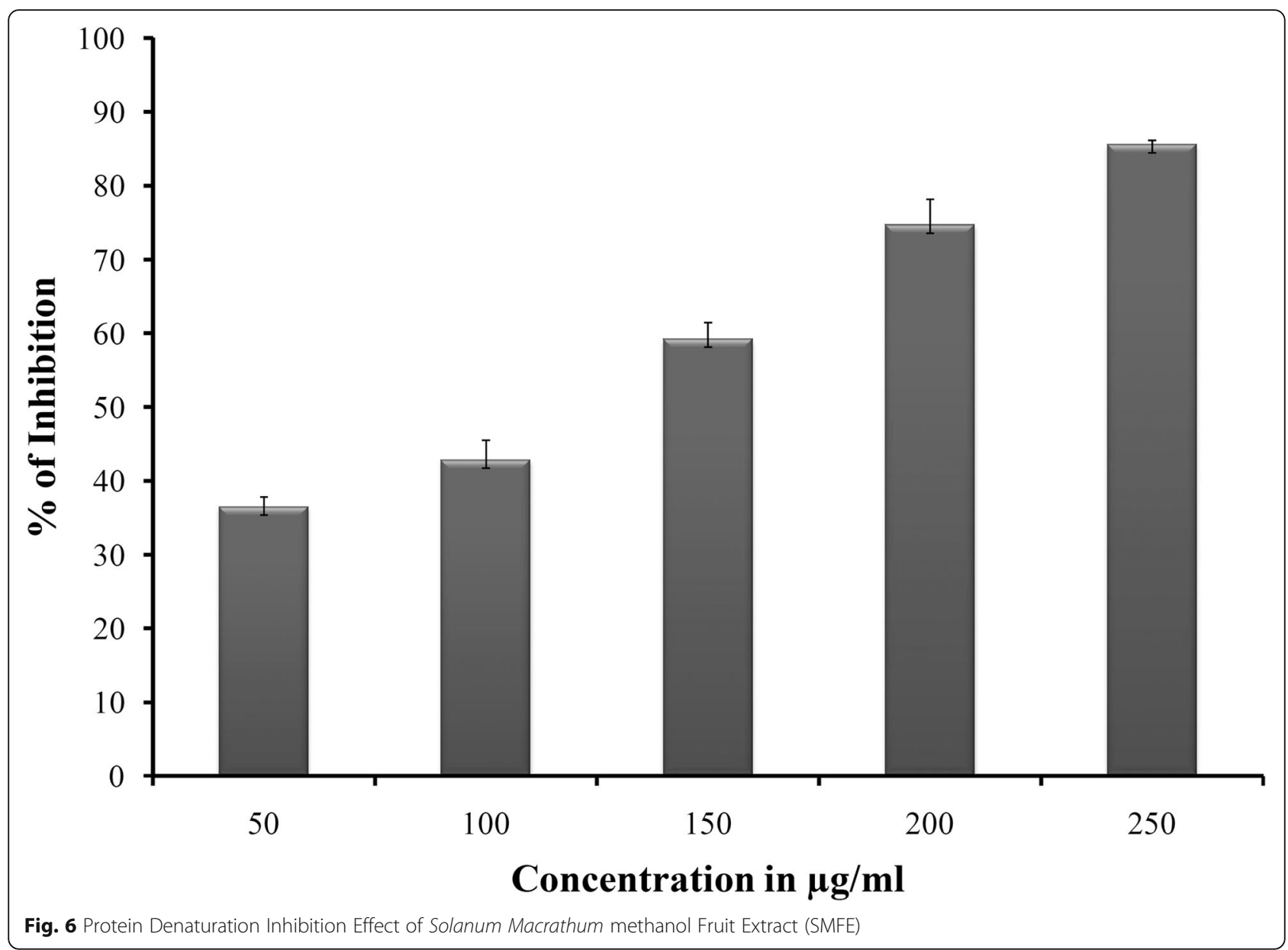

ferrous ion $\left(\mathrm{Fe}^{2+}\right)$ take place by donating electron. The methanolic extract of S.macranthum fruit was subjected to FRAP assay and ascorbic acid was used as standard. The methanol extract showed significant antioxidant activity with increase in concentration and $\mathrm{EC}_{50}$ value was calculated to be $515.144 \mu \mathrm{g} / \mathrm{ml}$. Ferric Reducing Antioxidant Power Assay of S.macranthum fruit methanol extract along with standard reference ascorbic acid is depicted in Fig. 4 and Table 4.

\section{2, 2-Diphenyl-1-picrylhydrazyl radical scavenging ability (DPPH) assay}

The assay is based on accepting of hydrogen donar by DPPH compound from antioxidant molecule. The methanol extract of S.macranthum fruit obtained was subjected to DPPH assay with ascorbic acid as reference. The extract showed a significant antioxidant activity with increase in the concentration and was maximum with $47.9 \%$ at $400 \mu \mathrm{g} / \mathrm{ml}$ and $\mathrm{EC}_{50}$ was calculated to be $426.112 \mu \mathrm{g} / \mathrm{ml}$. DPPH Assay of S.macranthum fruit methanol extract along with standard reference ascorbic acid is depicted in Fig. 5 and Table 4.

\section{Anti-inflammatory assay}

The SMFE showed a significant protein denaturation inhibitory effect in concentration dependant manner which has been depicted in the Fig. 6 and Table 5. The SMFE was found to have a maximum inhibition of protein denaturation of $85 \%$ at $250 \mu \mathrm{g}$ concentration which is at par with standard Diclofenac sodium whose percentage of inhibition was to found $73 \%$ at $100 \mu \mathrm{g} / \mathrm{ml}$. The $\mathrm{EC}_{50}$ of the SMFE was calculated to be $112.96 \mu \mathrm{g} /$ $\mathrm{ml}$.

Table 5 Anti-inflammatory effect of S.macranthum Fruit methanol extract (SFME)

\begin{tabular}{lll}
\hline Concentration $\mu \mathrm{g} / \mathrm{ml}$ & Absorbance at $660 \mathrm{~nm}$ & \% of Inhibition \\
\hline Control & $0.037 \pm 0.01$ & - \\
50 & $0.023 \pm 0.01^{*}$ & 36.36364 \\
100 & $0.021 \pm 0.01^{* *}$ & 42.72727 \\
150 & $0.014 \pm 0.01^{*}$ & 60.90909 \\
200 & $0.009 \pm 0.01^{* *}$ & 74.54545 \\
250 & $0.005 \pm 0.01^{* *}$ & 86.27273 \\
\hline
\end{tabular}

Data is presented as mean standard error of the mean $(n=3)$. Statistical significance was assessed using one-way ANOVA. ${ }^{*}=p<0.05^{* *}=p<0.01$. Significantly different in comparison with control 


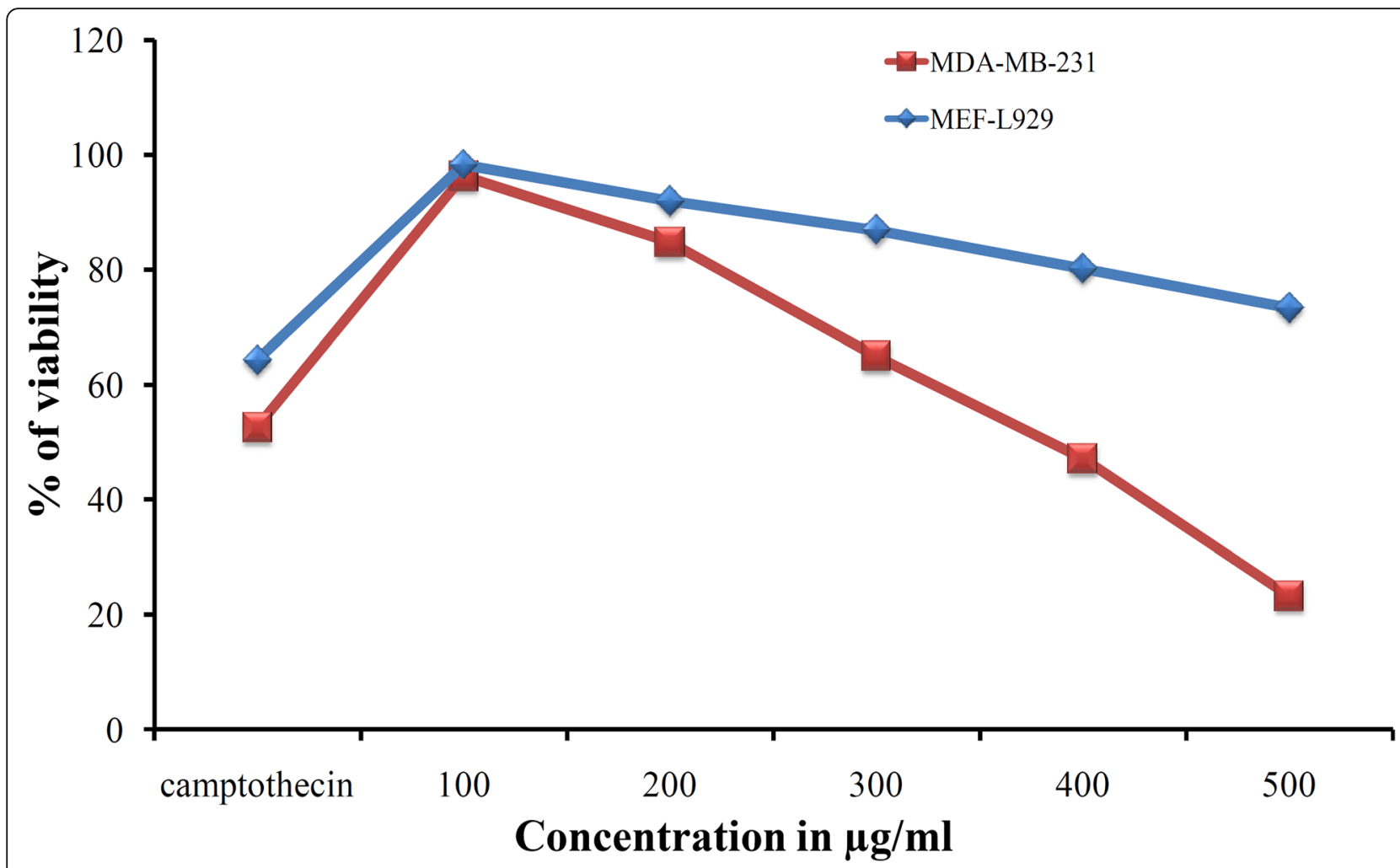

Fig. 7 Cytotoxic effect of S. macrathum methanol fruit extract on MDA-MB-231 and MEF-L929 cell lines

\section{Comparative cytotoxic evaluation of S.macranthum} methanol fruit extract on MDA-MB-231 and MEF-L929 cell line

MTT assay measures the cell proliferation rate and conversely when metabolic activity decreased eventually leads to apoptosis or necrosis, representing reduction in cell viability. The methanolic extract of S.macranthum fruit through MTT assay revealed significant cytotoxic effect on MDA-MB-231 cell line, however no growth inhibition was induced on MEFL929 cells. The cytotoxic effect of the methanolic extract had similar effects as that of standard camptothecin against MDA-MB-231 cell lines. Morphologically the MDA-MB-231 cells appeared to be shrink, followed by the death of the cells induced by the methanolic extract of S.macranthum fruit. The $\mathrm{IC}_{50}$ value of S.macranthum fruit methanolic extract was $373.77 \mu \mathrm{g} / \mathrm{ml}$ against MDA-MB-231 breast cancer cell lines. However, S.macranthum fruit methanolic extract showed negligible toxicity against normal cell line MEF-L929, where in the highest tested concentration $(500 \mu \mathrm{g} / \mathrm{ml})$ itself showed $73.29 \%$ cell viability, whereas the $\mathrm{IC}_{50}$ was found out to be in negative concentration hence revealing its non toxic property against normal cells. This study clearly indicated the cancer specific cytotoxic effect of S.macranthum fruit methanolic extract (Figs. 7 and 8 and Table 6).

\section{Discussion}

Plant derived compounds are drawing a great interest due to their versatile applications, they have been richest bio-source of drugs among the traditional medicine, modern medicine, food supplements and as well as chemical entities of synthetic drugs [18]. The qualitative phytochemical analysis of the S.macranthum fruit had been carried for four different solvent extracts i.e., petroleum ether, chloroform, methanol and water extract. Among them methanol extract was found to be positive for various phytoconstituents such as alkaloids, tannins, terpeniods, flavonoids, saponins and phenols [8]. The prominent phytoconstituents which are reported for their importance in combating with various diseases and disorders are likely to be alkaloids, flavonoids and phenols. These bioactive compounds have predominantly available in the vast variety of plant species. In this study the methanol extract of S.macranthum fruit expressed a greater amount of these bioactive compounds, among these alkaloid concentration $(13,600 \mathrm{mg} / 100 \mathrm{~g})$ tend to be higher followed by flavonoids (142.6 mg/QE) and phenols (115.5 mg/GAE). These bioactive compounds also display a potentially antioxidant property.

Reactive oxygen species (ROS) majorly constitute as pathological factor involved in serious diseases, neurodegenerative disorders, damaging the cells and one of the 


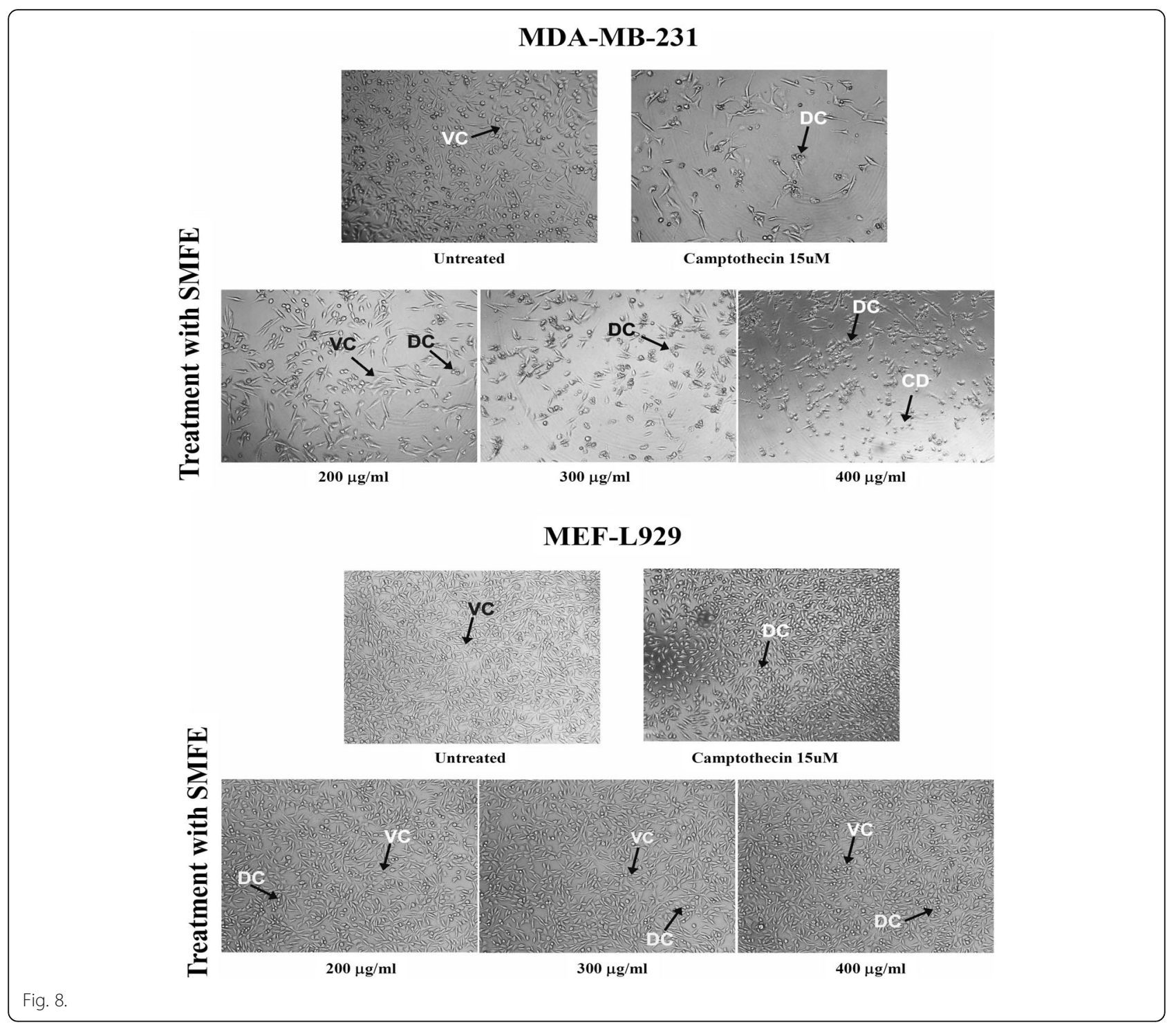

causative factors to induce cancer. There are reports which signifies and implies that oxidative stress has significant correlation between the occurrences of breast cancer especially in premenopausal women [19]. Many of the phytoconstituents have the ability to suppress these free radicals by donating the electrons and balancing their valences [20]. Solanum species are known to possess a great variety of medicinal properties including antitumorigenic, antioxidant, anti-inflammatory, hepatoprotective, diuretic, antipyretic, microbicidal, cytotoxic, anti-convulsant, antiulcerogenic and also against sexually transmitted diseases [21]. The study focused on evaluating the antioxidant property of Solanum macranthum extract, since there have been no reports of antioxidant activity of the plant till date. The methanol extract of the S.macranthum fruit was tested for their antioxidant properties by subjecting to the $\mathrm{H}_{2} \mathrm{O}$ Assay, DPPH assay and FRAP assay. Hydrogen peroxide $\left(\mathrm{H}_{2} \mathrm{O}_{2}\right)$ assay is one if the most widely accepted assay to determine the antioxidant activity of any compound, the activity is based on the ability of antioxidant to inhibit the formation of hydroxyl radicals and malondialdehyde (MDA) and there by reduce or prevent the degradation of 2-deoxyribose [20]. When methanol extract of S.macranthum fruit was tested for its antioxidant activity by $\mathrm{H}_{2} \mathrm{O}_{2}$ assay, it had similar antioxidant activity at par with reference standard ascorbic acid at $200 \mu \mathrm{g} / \mathrm{ml}$ concentration, but at $400 \mu \mathrm{g} / \mathrm{ml}$ concentration the antioxidant activity of methanol extract increased appreciably than reference ascorbic acid, with $\mathrm{EC}_{50}$ value of $51.872 \mu \mathrm{g} / \mathrm{ml}$, which reveals that methanol extract of S.macranthum fruit had major radical scavenging activity.

FRAP assay, based on the reduction of ferric tripyridyltriazine complex to its ferrous colored form. This 
Table 6 Cytotoxic effect of S.macranthum Fruit methanol extract (SFME) on MDA-MB-231 and MEF-L929 cell line

\begin{tabular}{|c|c|c|c|c|}
\hline \multirow[b]{2}{*}{ Concentration $\mu \mathrm{g} / \mathrm{ml}$} & \multicolumn{2}{|l|}{ MDA-MB-231 } & \multicolumn{2}{|l|}{ MEF-L929 } \\
\hline & Absorbance at $630 \mathrm{~nm}$ & $\%$ of Viability & Absorbance at $630 \mathrm{~nm}$ & $\%$ of Viability \\
\hline Blank & $0.04 \pm 0.01$ & - & $0.04 \pm 0.01$ & - \\
\hline Control & $1.13 \pm 0.15^{* *}$ & 100 & $0.61 \pm 0.01^{* *}$ & 100 \\
\hline 100 & $1.08 \pm 0.16^{*}$ & 96.27 & $0.90 \pm 0.01^{* *}$ & 98.29 \\
\hline 200 & $0.96 \pm 0.14^{*}$ & 84.74 & $0.85 \pm 0.01^{* *}$ & 91.93 \\
\hline 300 & $0.75 \pm 0.06^{* *}$ & 64.89 & $0.80 \pm 0.01^{* *}$ & 86.87 \\
\hline 400 & $0.55 \pm 0.02^{* *}$ & 47.08 & $0.75 \pm 0.01^{* *}$ & 80.17 \\
\hline 500 & $0.29 \pm 0.01^{* *}$ & 23.14 & $0.68 \pm 0.01^{* *}$ & 73.29 \\
\hline Camptothecin (15uM) & $0.61 \pm 0.09^{*}$ & 52.51 & $0.92 \pm 0.01^{* *}$ & 64.26 \\
\hline
\end{tabular}

Data is presented as mean standard error of the mean $(n=3)$. Statistical significance was assessed using one-way ANOVA. ${ }^{*}=p<0.05 * *=p<0.01$. Significantly different in comparison with Blank

reduction of 2,4,6-Tripyridyl-S-Triazine (TPTZ)-Fe (III) complex to TPTZ-Fe(II) by the methanolic extract of S.macranthum fruit was used to assess the total reducing power of antioxidants. Under the acidic condition when an $\mathrm{TPTZ}^{-} \mathrm{Fe} 3^{+}$complex is reduced by electron donating antioxidants, the change from colourless $\mathrm{Fe}^{3+}$ to blue colored $\mathrm{Fe}^{2+}$ was measured at $593 \mathrm{~nm}$ [22]. The results revealed that methanolic extract had prominent antioxidant activity with increase in the concentration and with $\mathrm{EC}_{50}$ value of $515.144 \mu \mathrm{g} / \mathrm{ml}$, establishing that the bioactive compounds present in the methanol extract of S.macranthum fruit has an notable antioxidant property.

DPPH Assay is based on hydrogen donating ability of the compound. The DPPH free organic nitrogen radical is very stable which contains an odd electron when reacts with antioxidant compounds that can donate hydrogen atoms, after accepting the electron it reduces and the purple color is changed to yellow. This degree of reduction in absorbance measurement at $512 \mathrm{~nm}$ is indicative of scavenging potential of compounds [23]. From the experimental data methanolic extract showed properties of scavenging the free radicals $\left(\mathrm{EC}_{50}=426.112 \mu \mathrm{g} / \mathrm{ml}\right)$ and posses antioxidant activity with increase in the concentration.

Denaturation of the proteins has been well documented as cause inflammation in the individual. When external stress or compound, such as strong acid or base, a concentrated inorganic salt, organic solvent or heat is exerted on these proteins loses its primary and secondary structure configuration. Under such condition most of the biological proteins get denatured [24].

Precisely chronic inflammation has also been implicated to complications such as arthritis, stroke, and cancer [25]. There has been an substantial epidemiologic and experimental data which configures significant role of inflammation has impacted in establishment, progression, and/or aggressiveness of various malignancies, for most of the biological entities involved in signaling pathways in apoptosis, cell proliferation, and angiogenesis were found to be common in both inflammation and carcinogenesis [26]. As part of the current investigation the SMFE exhibited its anti-inflammatory property ranging from $36.36 \%$ to $85.45 \%$ with $\mathrm{EC}_{50}$ value of $112.96 \mu \mathrm{g} / \mathrm{ml}$, signifying its ability to inhibit the protein denaturation at par with standard drug.

The bioactivity assessment of plant extracts its ability to inhibit the proliferation of cancerous cells will help in its utilization as a therapeutic agent [27]. For evaluating the preliminary cytotoxic effect of the synthetic derivatives, natural products and natural products extracts MTT assay is most widely preferred, where the reduction of tetrazolium salts by mitochondrial dehydrogenase by pur-ple formazan product [28].

Various reports have been documented of Solanaceae family for their medicinal applications [29]. Among them few of the species have proven to have anticancer property but at very higher concentration such as, methanol extract of S.nigrum ripe berries had effective cytotoxic activity with $\mathrm{IC}_{50}$ value of $4.8 \mathrm{mg} / \mathrm{ml}$ on HL-60 promyelocytic leukemia cell line [23] and on HeLa cell line having $\mathrm{IC}_{50}$ value of $265.0 \mathrm{mg} / \mathrm{ml}$ [30]. Ethyl acetate leaves extract of Solanum anguivi was found to be toxic for HepG2 and MCF-7 cell lines whose $\mathrm{IC}_{50}$ value was reported to be $0.625 \mathrm{mg} / \mathrm{ml}$ and $1.25 \mathrm{mg} / \mathrm{ml}$ respectively [31]. On the Ehrlich Ascites Carcinoma cells (EAC) the ethanolic extract of Solanum torvum fruit berries showed its toxicity with $\mathrm{IC}_{50}$ value of $600 \mu \mathrm{g} / \mathrm{ml}$ [32]. This cytotoxic effect is majorly due to certain bioactive active compounds such as glycoalkaloids, solamargine, solasodine, and solasonine, found in these species specially solamargine are responsible to induce apoptosis in cancer cell lines [33-35].

In this study, the in vitro cytotoxicity was assessed using non cancerous L929-Mouse fibroblast Cell Line and MDA-MB- 231 breast cancer Cell line. The results obtained revealed that the methanol extract significantly inhibited the growth of MDA-MB- 231 cell line with $\mathrm{IC}_{50}$ value of $373.77 \mu \mathrm{g} / \mathrm{ml}$ which is considerably higher 
cytotoxic effect than the solanum plant species stated above, while the methanol extract of S.macranthum fruit did not exhibit any toxicity against proliferation of normal MEF-L929 cells even at higher concentration. The results also confirmed that the differential effect induced by the extracts and standard drug in cancerous and normal cells. As a result the inhibition of the growth of the cancerous cells by S.macranthum methanol fruit extract can be conceivably due to the several bioactive components present in them.

\section{Conclusion}

In conclusion methanol extract of the S.macranthum exhibits strong antioxidant potential, anti-inflammatory response and possess specific cytotoxic effect towards breast cancer cells while posing no toxic effect on the normal cell line. Thus further investigations should be made in order to find the potential bioactive phytoconstituent present in the fruit of S.macranthum and assess its anticancer effects in in-vivo models.

\section{Acknowledgements}

The authors would like to acknowledge Karnatak University Dharwad and P.C Jabin Science College Hubballi for providing the laboratory facility to carry out the research. The authors would also like to acknowledge the support rendered by Cytxon Biosolutions Pvt. Ltd. Hubbali.

\section{Authors' contributions}

VUK: Accomplishment of the experimental works as well as analysis and acquisition of data. $\mathrm{JHH}$ : - Study design of the experiment and final draft of the manuscript. SVH:- reviewed and gave critical analysis of the manuscript $\mathrm{MBH}$ : Supervised and designed the study as well as drafted and corrected all versions of the manuscript. All authors read and approved the final manuscript.

\section{Funding}

This research study was not granted any specific fund.

\section{Availability of data and materials}

The datasets supporting the conclusions of this article are included within the article.

\section{Ethics approval and consent to participate}

Not applicable.

\section{Consent for publication}

Not applicable.

\section{Competing interests}

The authors declare that they have no competing interests.

\section{Author details}

${ }^{1}$ Department of Biotechnology and Microbiology, Karnatak University, Dharwad, Karnataka, India. ${ }^{2}$ Department of Biotechnology, P.C. Jabin Science College, Vidyanagar, Hubballi, Karnataka 580031, India. ${ }^{3}$ Department of Bioinformatics and Biotechnology, Karnataka State Akkamahadevi Women's University, Vijayapura, Karnataka 568108, India.

Received: 8 June 2019 Accepted: 12 March 2020

Published online: 23 April 2020

\section{References}

1. Singh D, Singh P, Gupta A, Solanki S, Sharma E, Nema R. Qualitative estimation of the presence of bioactive compound in Centella asiatica: an important medicinal plant. Int J Life Sci Med Sci. 2012;2:4-7.
2. Kulkarni BB, Kulkarni SS, Hallikeri UR, Patil BR, Gai PB. Decade of breast cancer-trends in patients profiles attending tertiary cancer care center in south India. Asian J Epidemiol. 2012;5:103-3.

3. Ali R, Mathew A, Rajan B. Effects of socio-economic and demographic factors in delayed reporting and late-stage presentation among patients with breast cancer in a major cancer hospital in South India. Asian Pac J Cancer Prev. 2008;4:703-7.

4. Hortobagyi GN. Multidisciplinary management of advanced primary and metastatic breast cancer. Cancer. 1994;74:416-23.

5. Sateesh MK, Mohsin B. Screening of the ethnobotanicals against MDA-MB231 and MCF-7 breast cancer cell lines. Int J Phytopharmacy. 2014;4:140-7.

6. Essien EE, Walker TM, Newby JM, Ogunwande IA, Setzer WN, Ekundayo O. The floral essential oil composition and biological activity of Solanum macranthum Dunal. Am J Essent Oils Nat Prod. 2016;4:36-9.

7. Yadav R, Rathi M, Pednekar A, Rewachandani Y. A detailed review on Solanaceae family. Euro J Pharm Med Res. 2016;3:369-78.

8. Kalebar VU, Hoskeri JH, Hiremath SV, RV ABK, Sonappanavar KL, Agadi BS, et al. Pharmacognostical and phytochemical analysis of Solanum macranthum (Dunal) Fruits. J Pharmacogn Phytochem. 2019;8:284-90.

9. Senguttuvan J, Paulsamy S, Karthika K. Phytochemical analysis and evaluation of leaf and root parts of the medicinal herb, Hypochaeris radicata L. for in vitro antioxidant activities. Asian Pac J Trop Biomed. 2014;4:59-67.

10. Zhishen J, Mengcheng T, Jianming $W$. The determination of flavonoid contents in mulberry and their scavenging effects on superoxide radicals. Food Chem. 1999:64:555-9.

11. Siddhuraju P, Becker K. Antioxidant properties of various solvent extracts of total phenolic constituents from three different agroclimatic origins of drumstick tree (Moringa oleifera Lam.) leaves. J Agr Food Chem. 2003;51: 2144-55.

12. Benzie IF, Strain JJ. The ferric reducing ability of plasma (FRAP) as a measure of "antioxidant power": the FRAP assay. Anal Biochem. 1996;239:70-6.

13. Keser S, Celik S, Turkoglu S, Yilmaz O, Turkoglu I. Hydrogen peroxide radical scavenging and total antioxidant activity of hawthorn. Chem J. 2012;2:9-12.

14. Brand-Williams W, Cuvelier ME, Berset CL. Use of a free radical method to evaluate antioxidant activity. LWT-Food Sci Technol. 1995;28:25-30.

15. Chandra S, Chatterjee P, Dey P, Bhattacharya S. Evaluation of antiinflammatory effect of ashwagandha: a preliminary study in vitro. Pharmacognosy J. 2012:4:47-9.

16. Sangeetha M, Kousalya K, Lavanya R, Sowmya C, Chamundeeswari D, Reddy CU. In-vitro anti-inflammatory and anti-arthritic activity of leaves of Cleodendron inerme. Res J Pharm Biol Chem Sci. 2011;2:822-7.

17. Alley MC, Scudiero DA, Monks A, Czerwiski MJ, Shoemaker RH, Boyd MR. Variation of an automated microculture tetrazolium assay (MTA) to assess cell growth and drug sensitivity of human tumor cell lines. InProc Am Assoc Cancer Res 1986:2:389.

18. Tiwari P, Kumar B, Kaur M, Kaur G, Kaur H. Phytochemical screening and extraction: a review. Internationale pharmaceutica sciencia. 2011:1:98-106.

19. Ambrosone CB, Freudenheim JL, Thompson PA, Bowman E, Vena JE, Marshall JR, et al. Manganese superoxide dismutase (MnSOD) genetic polymorphisms, dietary antioxidants, and risk of breast cancer. Cancer Res. 1999;59:602-6.

20. Afsar T, Razak S, Shabbir M, Khan MR. Antioxidant activity of polyphenolic compounds isolated from ethyl-acetate fraction of Acacia hydaspica $\mathrm{R}$. Parker. Chem Cent J. 2018;12:5.

21. Jayakumar K, Meenu Krishnan VG, Murugan K. Evaluation of antioxidant and antihemolytic activities of purified caulophyllumine-A from Solanum mauritianum Scop. J Pharmacogn Phytother. 2016;5:195-9.

22. Muselík J, García-Alonso M, Martín-López MP, Žemlička M, Rivas-Gonzalo JC. Measurement of antioxidant activity of wine catechins, procyanidins, anthocyanins and pyranoanthocyanins. Int J Mol Sci. 2007:8:797-809.

23. Bokhari J, Khan MR, Shabbir M, Rashid U, Jan S, Zai JA. Evaluation of diverse antioxidant activities of Galium aparine. Spectrochim Acta A Mol Biomol Spectrosc. 2013;102:24-9.

24. Jayashree $\mathrm{V}$. $\mathrm{n}$ in-vitro anti-inflammatory activity of 4-benzylpiperidine. Asian J Pharm Clin Res. 2016;9;108-10.

25. Osman NI, Sidik NJ, Awal A, Adam NA, Rezali NI. In vitro xanthine oxidase and albumin denaturation inhibition assay of Barringtonia racemosa L. and total phenolic content analysis for potential anti-inflammatory use in gouty arthritis. J Intercult Ethnopharmacol. 2016:5:343.

26. Wong RS. Role of Nonsteroidal Anti-Inflammatory Drugs (NSAIDs) in cancer prevention and cancer promotion. Adv Pharmacol Sci. 2019;2019;1-10. 
27. Gabrani R, Jain R, Sharma A, Sarethy IP, Dang S, Gupta S. Antiproliferative effect of Solanum nigrum on human leukemic cell lines. Indian J Pharm Sci. 2012;74:451-3.

28. McCauley J, Zivanovic A, Skropeta D. Bioassays for anticancer activities. In Metabolomics Tools for Natural Product Discovery. 2013;1055:191-205.

29. Yu S, Sheu HM, Lee CH. Solanum incanum extract (SR-T100) induces melanoma cell apoptosis and inhibits established lung metastasis. Oncotarget. 2017;8:103509-17.

30. Patel S, Gheewala N, Suthar A, Shah A. In-vitro cytotoxicity activity of Solanum nigrum extract against Hela cell line and Vero cell line. Int J Pharmacy Pharm Sci. 2009;1:38-46.

31. Gandhiappan J, Rengasamy R. Antiproliferative activity of Solanum anguivi against cancer cell lines. Der Pharm Lett. 2012;4:875-80.

32. Panigrahi SW, Sundaram Muthuraman M, Natesan RA, Pemiah BR. Anticancer activity of ethanolic extract of Solanum torvum sw. Int J Pharmacy Pharm Sci. 2014;6:93-8.

33. Kupchan SM, Barboutis SJ, Knox JR, Cam CA. Beta-solamarine: tumor inhibitor isolated from Solanum dulcamara. Science. 1965;150:1827-8.

34. Cham BE, Meares HM. Glycoalkaloids from Solanum sodomaeum are effective in the treatment of skin cancers in man. Cancer Lett. 1987;36:111-8.

35. Liu LF, Liang CH, Shiu LY, Lin WL, Lin CC, Kuo KW. Action of solamargine on human lung cancer cells-enhancement of the susceptibility of cancer cells to TNFs. FEBS Lett. 2004;577:67-74.

\section{Publisher's Note}

Springer Nature remains neutral with regard to jurisdictional claims in published maps and institutional affiliations.

\section{Submit your manuscript to a SpringerOpen ${ }^{\circ}$ journal and benefit from:}

- Convenient online submission

- Rigorous peer review

- Open access: articles freely available online

High visibility within the field

- Retaining the copyright to your article

Submit your next manuscript at $\boldsymbol{\nabla}$ springeropen.com 